\title{
Correction to: Sargramostim to treat patients with acute hypoxic respiratory failure due to COVID-19 (SARPAC): A structured summary of a study protocol for a randomised controlled trial
}

Cedric Bosteels ${ }^{\dagger}$, Bastiaan Maes ${ }^{*}{ }^{\dagger}$, Karel Van Damme ${ }^{\dagger}$, Elisabeth De Leeuw ${ }^{\dagger}$, Jozefien Declercq ${ }^{\dagger}$, Anja Delporte, Bénédicte Demeyere, Stéfanie Vermeersch, Marnik Vuylsteke, Joren Willaert, Laura Bollé, Yuri Vanbiervliet, Jana Decuypere, Frederick Libeer, Stefaan Vandecasteele, Isabelle Peene and Bart N. Lambrecht

Correction to: Trials (2020) 21:49

https://doi.org/10.1186/s13063-020-04451-7

Following publication of the original article [1], we have been notified that an initial was missed from one of the author names.

Originally published author names:

- Bart Lambrecht

Correct author names:

- Bart N. Lambrecht

The original article has been corrected.

Published online: 22 June 2020

\section{Reference}

1. Bosteels, et al. Sargramostim to treat patients with acute hypoxic respiratory

failure due to COVID-19 (SARPAC): A structured summary of a study

protocol for a randomised controlled trial. Trials. 2020;21:491. https://doi.

org/10.1186/s13063-020-04451-7.

The original article can be found online at https://doi.org/10.1186/s13063020-04451-7.

*Correspondence: bastiaan.maes@irc.vib-ugent.be

${ }^{+}$Cedric Bosteels, Bastiaan Maes, Karel Van Damme, Elisabeth De Leeuw and Jozefien Declercq contributed equally to this work.

VIB-UGent Inflammatie-researchcentrum, Oost-Vlaanderen, Ghent, Belgium

(C) The Author(s). 2020 Open Access This article is licensed under a Creative Commons Attribution 4.0 International License, which permits use, sharing, adaptation, distribution and reproduction in any medium or format, as long as you give appropriate credit to the original author(s) and the source, provide a link to the Creative Commons licence, and indicate if changes were made. The images or other third party material in this article are included in the article's Creative Commons licence, unless indicated otherwise in a credit line to the material. If material is not included in the article's Creative Commons licence and your intended use is not permitted by statutory regulation or exceeds the permitted use, you will need to obtain permission directly from the copyright holder. To view a copy of this licence, visit http://creativecommons.org/licenses/by/4.0/. The Creative Commons Public Domain Dedication waiver (http://creativecommons.org/publicdomain/zero/1.0/) applies to the data made available in this article, unless otherwise stated in a credit line to the data. 